\title{
Model Pembelajaran TPS (Think-Pair-Share) Berbantuan Media Kartu Huruf Meningkatkan Kemampuan Mengenal Huruf pada Anak Kelompok B
}

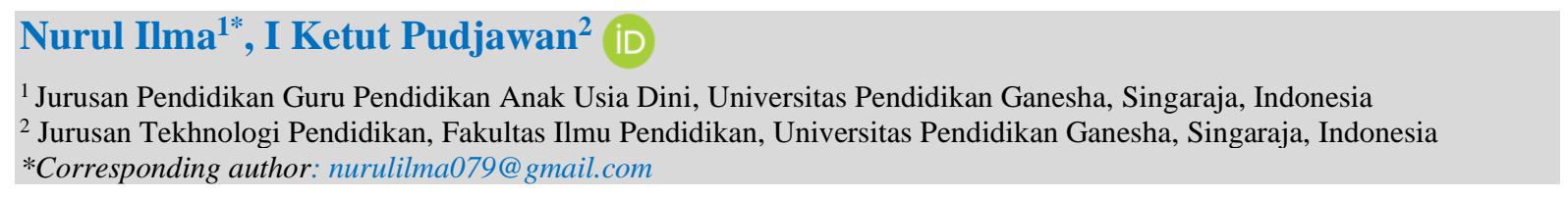

\section{Abstrak}

Masih belum optimalnya perkembangan bahasa anak khususnya pada pengenalan huruf. Penelitian ini bertujuan untuk menganalisis model pembelajaran think pair share berbantuan media kartu huruf terhadap kemampuan mengenal huruf pada anak kelompok B. Penelitian ini merupakan penelitian tindakan kelas (PTK) yang dilaksanakan dalam dua siklus. Subjek penelitian ialah kelompok B3 TK yang berjumlah 27 anak terdiri dari 9 anak perempuan dan 18 anak laki-laki. Objek penelitian adalah kemampuan bahasa anak dalam mengenal huruf. Pengumpulan data dalam penelitian ini dilakukan dengan media observasi. Metode analisis yang digunakan adalah metode analisis statistik deskriptif dan metode analisis deskriptif kuantitatif. Hasil analisis data pada penelitian ini menunjukkan bahwa terjadi peningkatan rata-rata presentase kemampuan bahasa mengenal huruf pada kelompok B3 sebesar $25.7 \%$ hal ini dapat dilihat dari adanya peningkatan rata-rata presentase kemampuan bahasa mengenal huruf anak pada siklus I sebesar $55.31 \%$ dengan kriteria rendah menjadi $81,01 \%$ pada siklus II dengan criteria tinggi. Berdasarkan hasil penelitian, dapat disimpulkan bahwa Penerapan model pembelajaran Think Pair Share berbantuan media kartu huruf dapat meningkatkan kemampuan mengenal huruf kelompok B Taman Kanak-Kanak.

Kata kunci: TPS, Kartu Huruf

\section{Abstract}

The development of children's language is still not optimal, especially in letter recognition. This study aims to analyze the think pair share learning model assisted by letter card media on the ability to recognize letters in group B children. This research is a classroom action research (CAR) which was carried out in two cycles. Research subjects are the B3 group totaling 27 children consisting of 9 girls and 18 boys. The object of research is the child's language ability in recognizing letters. Data collection in this study was carried out utilizing observation. The analytical method used is descriptive statistical analysis method and quantitative descriptive analysis method. The results of data analysis in this study showed that there was an increase in the average percentage of language skills to recognize letters in group B3 by 25,7\%, this can be seen from an increase in the average percentage of language skills to recognize children's letters in the first cycle of $55,31 \%$ with low criteria being $81,01 \%$ in cycle II with high criteria. So, it can be concluded that the application of the Think Pair Share learning model assisted by letter card media can improve the ability to recognize letters in kindergarten group $B$.

\section{INTRODUCTION}

Pendidikan Anak Usia Dini merupakan pendidikan yang diperuntukan bagi anak-anak sebelum memasuki jenjang pendidikan sekolah dasar. Pendidikan anak usia dini sangat penting bagi anak sebagai bekal persiapan pendidikan berikutnya. Pendidikan anak usia dini (PAUD) adalah jenjang pendidikan sebelum sekolah dasar yang merupakan suatu upaya dasar pembinaan yang ditujukan bagi anak sejak lahir sampai dengan usia enam tahun yang dilakukan melalui pemberian rangsangan pendidikan yang membantu pertumbuhan dan perkembangan jasmani dan rohani agar anak memiliki kesiapan dalam memasuki pendidikan lebih lanjut (Halimatus et al., 2019; Nadlifah, 2017; Nugraha, 2020; Swastrini et al., 2016). Salah satu perkembangan yang sangat penting untuk persiapan pada jenjang pendidikan sekolah dasar adalah perkembangan bahasa.

$\begin{array}{lll}\text { History: } & & \text { Publisher: Undiksha Press } \\ \text { Received } & \text { : March 13, 2021 } & \text { Licensed: This work is licensed under } \\ \text { Revised } & \text { : March 20, 2021 } & \text { a Creative Commons Attribution 3.0 License } \\ \text { Accepted } & \text { : April 30, 2021 } & \text { CC (C) O) }\end{array}$


Perkembangan bahasa sangatlah penting untuk kehidupan anak di masa mendatang karena perkembangan bahsa adalah perkembangan yang digunakan anak untuk mempelajari segala ilmu dan sebagai alat komunikasi yang di pahami semua manusia. Perkembangan bahasa anak beda halnya dengan perkembangan pada manusia dewasa karena dimasa ini anak-anak masih cenderung tertarik dengan hal yang bernuansa permainan dan menggunakan pendekatan yang berorietasi belajar melalui bermain dengan pelaksanaan belajar melalui bermain pengalaman-pengalaman yang ditemukan oleh anak akan lebih melekat pada otaknya dan lebih menunjang pada daya ingatnya. Pada perkembangan anak usia dini pengenalan huruf merupakan bagian dari aspek perkembangan bahasa anak yang perlu di kembangkan dengan memberi stimulasi secara optimal sejak usia dini karena perkembangan, mengenal huruf adalah pondasi anak untuk bisa membaca dan untuk mempersiapkan anak pada jenjang pendidikan dasar (Anggraini et al., 2019; Mayasari \& Ardhana, 2018; Yulsyofriend et al., 2019). Stimulasi pengenalan huruf adalah merangsang anak untuk mengenali, memahami, dan menggunakan symbol tertulis untuk berkomunikasi. Perkembangan bahasa memerlukan bimbingan yang lebih optimal karena sebagai modal anak untuk memasuki jenjang pendidikan sekolah dasar.

Berdasarkan hasil observasi yang dilakukan di kelompok B3 TK Kartika VII-3 Singaraja diperoleh hasil kemampuan bahasa khususnya kemampuan mengenal huruf belum berkembang secara maksimal. Dibandingkan dengan aspek perkembangan kognitif, fisik motorik, seni, sosial emosional dan Nilai agama moral. Dari 27 anak kelompok B3 ditemukan 20 anak mengalami kesulitan dalam mengenal huruf, taraf perkembangan masih pada tahap penilaian MB (Mulai berkembang). Sedangkan 7 anak lainnya taraf penilaian BSH (Berkembang sesuai harapan). Pada obeservasi ini belum ditemukan anak yang penilaiannya pada taraf BSB (Berkembang sangat baik). Kesulitan anak nampak apabila disuruh menyebutkan huruf dengan system acak.

Permasalahan tersebut jika dibiarkan akan memberikan dampak negative pada proses pembelajaran di TK tersebut. Maka diperlukan solusi untuk permasalahan tersebut. Solusi tersebut ialah menerapkan model pembelajaaran kooperatif yang dapat menarik minat siswa untuk belajar. Salah satunya ialah model pembelajaran Think Pair Share (TPS). Model pembelajaran Think Pair Share adalah salah satu model pembelajaran kooperatif yang menempatkan siswa secara berpasangan untuk menyelesaikan tugas-tugas akademik melalui tiga tahap, yaitu think (berfikir), pair (berpasangan), dan share (berbagi) (Amalia \& Surya, 2017; Tembang et al., 2017; Utaminingsih et al., 2018; Winantara \& Jayanta, 2017). Salah satu keutamaan model pembelajaran kooperatif tipe TPS yaitu dapat menumbuhkan keterlibatan dan keikutsertaan siswa dengan memberikan kesempatan terbuka pada siswa untuk berbicara dan mengutarakan gagasannya sendiri dan memotivasi siswa untuk terlibat percakapan dalam kelas. Dengan demikian penggunaan model pembelajaran kooperatif. Think Pair Share dapat membantu siswa dalam berkomunikasi matematik untuk menyampaikan informasi, seperti menyatakan ide, mengajukan pertanyaan dan menanggapi pertanyaan orang lain.

Selain penggunaan model pembelajaran yang tepat, penggunaan media pembelajaran juga sangat berpengaruh untuk minat dan hasil belajar anak. Maka diperlukan juga suatu media yang mampu menarik minat anak sehingga tidak merasa bosan. Salah satu media yang dapat dipadukan dalam pembelajaran dengan model think pair share adalah media kartu huruf. Media kartu huruf adalah media pembelajaran dengan menggunakan kertas yang berukuran tebal dan berbentuk persegi panjang yang ditulis atau ditandai dengan unsur abjad atau huruf tertentu (Hidayati et al., 2019; Lestari \& Susari, 2016; Salawati \& Suoth, 2020). Kartu huruf merupakan salah satu alat bantu pembelajaran yang termasuk dalam katagori Flash Card. Media pembelajaran ini mengandalkan kartu huruf yang menjadi faktor utama dalam proses pembelajaran. Kartu huruf dapat membantu guru mencapai tujuan intruksional 
karena selain merupakan media yang murah dan mudah diperoleh, juga dapat meningkatkan keaktifan siswa (Asri et al., 2013; Prasetiyorini, 2020; Rahayuningsih et al., 2019). Selain itu, pengetahuan dan pemahaman siswa menjadi lebih luas, jelas, dan tidak mudah dilupakan. Oleh karena itu, melalui media kartu huruf diharapkan dapat membantu siswa dalam proses pembelajaran. Melalui proses pembelajaran maka diharapkan siswa mendapat hasil belajar yang baik. Perubahan itu diupayakan dalam proses belajar mengajar untuk mencapai tujuan yang di harapkan.

Beberapa penelitian yang relevan dengan penelitian ini seperti yang dilakukan oleh (Salawati \& Suoth, 2020) yang menemukan bahwa terdapat pengeruh media kartu huruf terhadap kemampuan membaca permulaan. Kemudian penelitian lain juga dilakukan dan menemukan bahwa adanya peningkatan pengembangan berbahasa anak melalui metode bermain dengan kartu huruf (Rahayuningsih et al., 2019). Kemudian penelitian lain juga menemukan bahwa model pembelajaran kooperatif tipe think pair share dapat meningkatkan kemampuan berbicara anak (Uloli, 2021). Tujuan penelitian ini menganalisis model pembelajaran think pair share berbantuan media kartu huruf terhadap kemampuan mengenal huruf pada anak kelompok B.

\section{MATERIALS AND METHODS}

Penelitian ini merupakan penelitian Tindakan kelas (PTK). Penelitian ini dilaksanakan di kelompok B3 pada Semester I di TK Kartika VII-3. Pelaksanaan penelitian ini dilaksanakan dalam siklus tindakan. Setiap siklus dalam penelitian ini terdiri dari empat tahapan yaitu tahap perencanaan, tahap pelaksanaan, pengamatan, dan refleksi. Rancangan penelitian tindakan kelas dapat dilihat pada Gambar 1. Subjek dalam penelitian ini adalah anak kelompok B3 Semester I TK Kartika VII-3 Singaraja, dengan jumlah anak sebanyak 27 orang, yang terdiri dari 9 orang anak perempuan dan 18 orang anak laki-laki. Objek dalam penelitian ini adalah kemampuan bahasa pengenalan huruf terkait penerapan model pembelajaran think pair share (TPS) pada anak kelompok B3 TK Kartika VII-3 Singaraja.

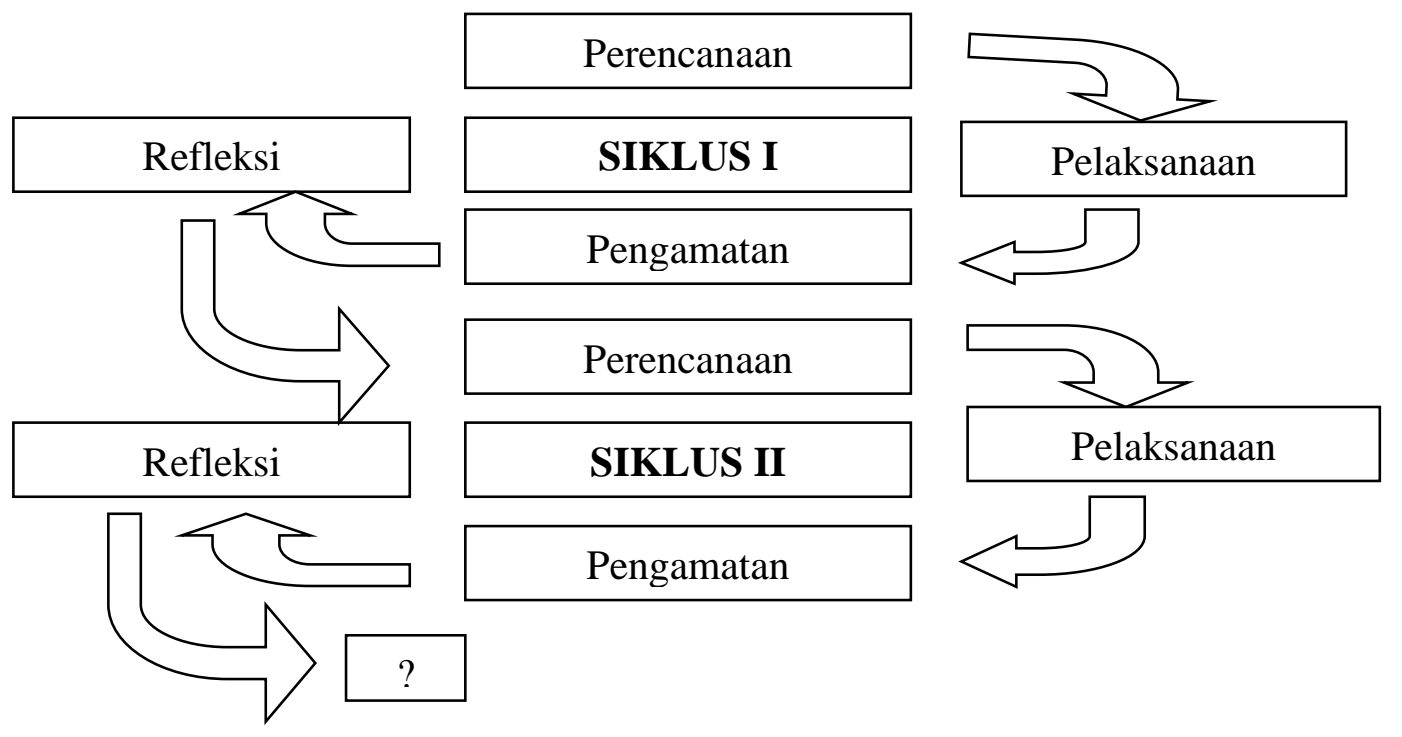

Gambar 1. Rancangan Penelitian Tindakan Kelas

(Arikunto, 2013)

Pengumpulan data dalam penelitian ini menggunakan metode observasi dan metode pencatatan dokumen. Penelitian ini menggunakan pencatatan dokumen digunakan untuk 
mengumpulkan data kemampuan bahasa lisan anak. Instrumen pengumpulan data yang digunakan dalam penelitian ini adalah lembar observasi. Penelitian ini menggunakan metode analisis statistik deskriptif dan metode analisis deskriptif kuantitatif. Metode analisis deskriptif kuantitatif ini digunakan untuk menentukan tinggi rendah data kemampuan bahasa mengenal huruf yang ditentukan dengan menggunakan pedoman konversi Penilaian Acuan Patokan (PAP) skala lima. Tingkat kemampuan bahasa mengenal huruf yang diperoleh anak hasilnya dikonversikan dengan cara membandingkan angka rata-rata persen dengan kriteria penilaian acuan patokan (PAP) skala 5. Pedoman Konversi PAP Skala 5 dapat dilihat pada Tabel 1.

Tabel 1. Pedoman Konversi PAP Skala Lima tentang Tingkat Kemampuan Bahasa Lisan

\begin{tabular}{|c|c|}
\hline Persentase Kemampuan Bahasa Lisan & Kriteria Kemampuan Bahasa Lisan \\
\hline $90-100$ & Sangat Tinggi \\
\hline $80-89$ & Tinggi \\
\hline $65-79$ & Sedang \\
\hline $55-64$ & Rendah \\
\hline $0-54$ & Sangat Rendah \\
\hline
\end{tabular}

(Koyan, 2012)

Kriteria keberhasilan pada penelitian ini adalah adanya peningkatan dalam kemampuan bahasa mengenal huruf pada anak kelompok B3 TK Kartika VII-3 Singaraja. Penelitian ini dinyatakan berhasil jika terjadi peningkatan skor rata-rata dari siklus I ke siklus II dan jika dikonversikan pada pedoman PAP Skala lima tentang tingkat kemampuan bahasa keaksaraan anak berada pada rentang 80-89 dengan kriteria tinggi.

\section{RESULTS AND DISCUSSION}

\section{Hasil Penelitian}

Penelitian tindakan kelas ini dilaksanakan pada anak kelompok B3 TK Kartika VII-3 Singaraja tahun 2018/2019 dengan jumlah subjek sebanyak 27 anak yang terdiri dari 9 orang anak perempuan dan 18 orang anak laki-laki. Penelitian ini dilaksanakan dalam II siklus. Tema yang digunakan pada saat penelitian ini berlangsung, mengikuti tema yang diterapkan oleh sekolah yaitu tema binatang. Data yang dikumpulkan adalah data tentang kemampuan bahasa mengenal huruf anak setelah diterapkan model pembelajaran Think Pair Share (TPS) dan menggunakan berbantuan media kartu huruf. Data tersebut dianalisis dengan menggunakan metode analisis statistik deskriptif dan metode analisis deskriptif kuantitatif. Kegiatan penelitian ini dilaksanakan pada bulan September - Oktober 2018. Hasil penelitian tersebut dapat dipaparkan sebagai berikut.

Pada siklus I dilaksanakan mulai dari tanggal 25 September sampai 28 September 2018 yang dilaksanakan dalam 4 kali pertemuan untuk melaksanakan penerapan dan 1 kali untuk melaksanakan evaluasi. Pelaksanaan siklus I ini dilaksanakan berdasarkan perencanaan pelaksanaan pembelajaran yang telah dibuat sebelumnya. Rencana Pelaksanaan Pembelajaran Mingguan serta Rencana Pelaksanaan Pembelajaran Harian (terlampir). Adapun tema pada siklus I ini adalah Tema Binatang.

Berdasarkan hasil analisis data diketahui bahwa Modus $<$ Median $<$ Mean $(7<8<$ 8,85 ), sehingga dapat dikatakan bahwa sebaran data-data kemampuan bahasa mengenal huruf pada siklus I merupakan kurva juling positif. Dengan demikian dapat diinterpretasikan bahwa skor kemampuan bahasa mengenal huruf pada anak kelompok B3 di TK Kartika VII-3 Singaraja cenderung rendah. Sedangkan untuk menghitung tingkat kemampuan bahasa mengenal huruf anak dapat dihitung dengan membandingkan rata-rata persentase (M\%) 
dengan Kriteria Pedoman Acuan Patokan (PAP) skala lima. Nilai M\%=55,31 \% yang dikonversikan kedalam PAP skala lima berada pada tingkat penguasaan 55-64 yang berarti bahwa tingkat kemampuan bahasa lisan anak pada siklus I berada pada kriteria rendah. Berdasarkan hasil penelitian tersebut, maka dapat diketahui bahwa tingkat kemampuan bahasa mengenal huruf pada siklus I masih berada pada kriteria rendah. Adapun kendalakendala dan kekurangan penerapan model pembelajaran Think Pair Share (TPS) pada siklus I adalah sebagai 1) penjelasan guru terlalu cepat, sehingga beberapa anak kebingungan saat belajar kelompok, 2) keaktifan anak masih kurang terlihat hanya beberapa anak yang mau menjawab pertanyaan guru dan tampil ke depan kelas, 3) bentuk kartu huruf kurang bervariasi, sehingga anak mulai terlihat bosan pada akhir pertemuan pada siklus I. Untuk mengatasi kendala-kendala tersebut, dalam melaksanakan siklus II akan dilakukan hal-hal diantaranya 1) menjelaskan kembali langkah-langkah model pembelajaran Think Pair Share (TPS) pada anak, 2) membimbing dengan baik anak yang mempunyai kemampuan akademik tinggi agar dapat dan mampu menularkan pengetahuan anak kepada anak yang kurang aktif, 3) menambah variasi warna pada kartu huruf dengan warna yang menarik. Berdasarkan hasil refleksi tersebut, maka penelitian tindakan kelas ini perlu dilanjutkan ke siklus II untuk peningkatan dan penyempurnaan kemampuan bahasa mengenal huruf pada anak kelompok B3 di TK Kartika VII-3 Singaraja.

Pada siklus II dilaksanakan mulai dari tanggal 1 s/d 4 Oktober 2018 yang dilaksanakan dalam 4 kali pertemuan untuk melaksanakan penerapan dan 1 kali untuk melaksanakan evaluasi. Pelaksanaan siklus II ini dilaksanakan berdasarkan hasil dari refleksi sikus I. Rencana Pelaksanaan Pembelajaran Mingguan serta Rencana Pelaksanaan Pembelajaran Harian (terlampir). Adapun tema pada siklus II ini adalah Tema Binatang.

Berdasarkan hasil analisis data diketahui bahwa Mean < Median $<$ Modus $(12,96<13$ $<14$ ), sehingga dapat dikatakan bahwa sebaran data-data kemampuan bahasa keaksaraan pada siklus II merupakan kurva juling negatif. Dengan demikian dapat diinterpretasikan bahwa skor kemampuan bahasa lisan pada anak kelompok B3 di TK Kartika VII-3 Singaraja cenderung tinggi. Sedangkan untuk menghitung tingkat kemampuan bahasa mengenal huruf anak dapat dihitung dengan membandingkan rata-rata persentase (M\%) dengan Kriteria Pedoman Acuan Patokan (PAP) skala lima. Nilai M\%=81,01\% yang dikonversikan kedalam PAP skala lima berada pada tingkat penguasaan 80-89 yang berarti bahwa tingkat kemampuan bahasa lisan anak pada siklus II berada pada kriteria tinggi. Setelah dilaksanakan perbaikan dari proses pembelajaran sikus I, dalam pelaksanaan siklus II terjadi peningkatan yang dapat dilihat pada kemampuan bahasa mengenal huruf anak yang sebelumnya berada pada kriteria rendah meningkat menjadi kriteria tinggi. Adapun temuan-temuan yang diperoleh selama pelaksanaan siklus II diantaranya 1) anak yang awalnya masih bingung dengan penerapan model pembelajaran Think Pair Share sudah dapat mengikuti setiap langkah penerapannya secara berurutan, 2) anak yang awalnya kurang memahami konsep huruf sudah dapat mengetahuinya, 3) anak yang awalnya belum bisa bekerjasama sudah bisa bekerjasama dengan baik, 4) bimbingan serta motivasi tetap diberikan pada anak. Secara umum proses pembelajaran dengan menggunakan model pembelajaran Think Pair Share untuk meningkatkan kemampuan bahasa mengenal huruf anak kelompok B3 berlangsung sesuai dengan perencanaan dan telah mencapai indikator keberhasilan. Hal ini terlihat dari adanya peningkatan rata-rata persentase dari sikus I ke siklus II, sehingga penelitian ini tidak dilanjutkan ke siklus berikutnya.

\section{Pembahasan}

Berdasarkan hasil analisis data penelitian yang telah dilaksanakan dalam dua siklus menunjukkan terjadinya peningkatan kemampuan bahasa mengenal huruf anak kelompok B3 TK Kartika VII-3 Singaraja dengan menerapkan model pembelajaran Think Pair Share. 
Setelah dilaksanakan tindakan pada siklus I diperoleh rata-rata persentase pada kategori sedang dan pada siklus II dengan kategori tinggi. Hal ini menunjukkan adanya peningkatan rata-rata persentase kemampuan bahasa mengenal huruf anak dari siklus I ke siklus II. Terjadinya peningkatan kemampuan pengenalan huruf (keaksaraan) pada anak setelah penerapan model pembelajaran Think Pair Share berbantuan media kartu huruf dalam penelitian ini disebabkan rasa tertarik anak pada kegiatan dan media pembelajaran yang disajikan oleh guru sehingga anak dapat menyelesaikan tugas yang diberikan guru secara berkelompok, yang pada akhirnya mampu meningkatkan kemampuan mengenal huruf pada anak.Hal ini dikarenakan kelebihan pada model pembelajaran Think Pair Share yaitu mampu meningkatkan penguasaan akademik, mengajarkan keterampilan sosial dan membantu siswa untuk dapat berpikir kritis, serta meningkatkan pemahaman siswa dalam memahami konsepkonsep pembelajaran (Tembang et al., 2017; Winantara \& Jayanta, 2017). Selain itu, media kartu huruf juga membuat siswa merasa lebih bersemangat dalam mengikuti proses pembelajaran. Hal itu dikarenakan pemberian kartu huruf dalam belajar, baik secara individu maupun kelompok menyebabkan siswa terlibat langsung untuk mengenal huruf, menyusun huruf menjadi kata (Artini et al., 2013; Lestari \& Susari, 2016; Prasetiyorini, 2020).

Pemberian stimulasi guna meningkatkan kemampuan mengenal huruf juga perlu diberikan pada anak dengan cara yang tepat dan metode pembelajaran yang sesuai dengan perkembangan anak. Keunggulan dari model pembelajaran Think Pair Share adalah optimalisasi partisipasi anak yang artinya anak dituntut aktif dalam kelompok, saling berbagi informasi dan membantu ketika salah satu teman mengalami kesulitan (Puspitasari et al., 2016; Surayya et al., 2014; Tembang et al., 2017). Penerapan pembelajaran dengan berkelompok dan menggunakan media kartu huruf memberikan pengalaman kepada anak dalam mengenal huruf yang akan menjadi bekal persiapan anak untuk dasar belajar membaca. Anak yang dapat mengenal huruf dengan baik cenderung memiliki kemampuan membaca dengan lebih baik karena mengenal huruf adalah tahapan mendasar sebelum belajar membaca.

\section{CONCLUSION}

Penerapan model pembelajaran Think Pair Share berbantuan media kartu huruf dapat meningkatkan kemampuan mengenal huruf kelompok B Taman Kanak-Kanak. Disarankan para guru agar lebih kreatif dan inovatif dalam memilih model pembelajaran, metode pembelajaran serta media pembelajaran yang sesuai dengan Tema dan standar tingkat pencapaian perkembangan anak di laksanakan dengan cara yang menyenangkan supaya anak merasa tertarik dan mau mengikutinya.

\section{REFERENCES}

Amalia, P., \& Surya, E. (2017). Perbedaan Hasil Belajar Statistika antara Model Pembelajaran Kooperatif Tipe NHT dengan TPS. Kreano, Jurnal Matematika KreatifInovatif, 8(1), 8-14. https://doi.org/10.15294/kreano.v8i1.7682.

Anggraini, V., Yulsyofriend, Y., \& Yeni, I. (2019). Stimulasi Perkembangan Bahasa Anak Usia Dini Melalui Lagu Kreasi Minangkabau Pada Anak Usia Dini. Pedagogi : Jurnal Anak Usia Dini Dan Pendidikan Anak Usia Dini, 5(2), 73. https://doi.org/10.30651/pedagogi.v5i2.3377.

Arikunto, S. (2013). Dasar-Dasar Evaluasi Pendidikan. Bumi Aksara.

Artini, N. M. S., Jampel, I. N., \& Sudatha, I. G. W. (2013). Penerapan Metode Pemberian Tugas Berbantuan Media Kartu Huruf untuk Meningkatkan Kemampuan Mengenal Konsep Huruf Pada TK Kelompok B Tunas Mulia. Jurnal Pendidikan Anak Usia Dini 
Undiksha, 1(1). https://doi.org/http://dx.doi.org/10.23887/paud.v1i1.1109.

Asri, P. A. S., Suwatra, I. W., \& Ambara, D. P. (2013). Penerapan Metode Pemberian Tugas Berbantuan Media Kartu Huruf untuk Meningkatkan Kemampuan Mengenal Huruf Pada Anak Kelompok A2 Eka Dharma Singaraja. Jurnal Pendidikan Anak Usia Dini Undiksha, 1(1). https://doi.org/http://dx.doi.org/10.23887/paud.v1i1.1086.

Halimatus, H., Fridani, L., \& Meilani, S. M. (2019). Pengembangan Media Grafis untuk Pengenalan Life Science pada Anak Usia Dini. Jurnal Obsesi : Jurnal Pendidikan Anak Usia Dini, 4(1), 395. https://doi.org/10.31004/obsesi.v4i1.318.

Hidayati, R., YP, S., \& Artharina, F. P. (2019). Keefektifan Media Kartu Huruf terhadap Keterampilan Membaca Aksara Legena Siswa. Jurnal Penelitian Dan Pengembangan Pendidikan, 3(2), 112. https://doi.org/10.23887/jppp.v3i2.17388.

Koyan, I. W. (2012). Konstruksi Tes. Undiksha Press.

Lestari, P., \& Susari, H. D. (2016). Pengembangan Berbahasa Pada Anak Usia 4 - 5 Tahun Melalui Metode Bermain Kartu Huruf di TK PSM 2 Kawedanan Magetan Tahun Pelajaran 2014 / 2015. Jurnal CARE (Children Advisory Research and Education), 3(2). http://e-journal.unipma.ac.id/index.php/JPAUD/article/view/559.

Mayasari, D., \& Ardhana, N. R. (2018). Publikasi Bentuk Fungsi dan Kategori SintaksisTuturan Masyarakat Manduro sebagai Pendukung Perkembangan Bahasa Anak Usia Dini. Jurnal Obsesi: Jurnal Pendidikan Anak Usia Dini, 2(1), 51. https://doi.org/10.31004/obsesi.v2i1.7.

Nadlifah, N. (2017). Optimlisasi Kemampuan Interaksi Sosial Anak di PAUD Inklusi Ahsanu Amala Yogyakarta. Golden Age: Jurnal Ilmiah Tumbuh Kembang Anak Usia Dini, 1(1), 17-26. https://doi.org/https://doi.org/10.14421/jga.2016.11-02.

Nugraha, E. (2020). Implementasi Program Tahfizh Qur'an Di PAUD Inklusif Dengan Model HOTS. As-Sibyan: Jurnal Pendidikan Anak Usia Dini, 5(2), 95-106. https://doi.org/http://dx.doi.org/10.32678/as-sibyan.v5i2.3569.

Prasetiyorini, P. (2020). Pengaruh Penerapan Media Kartu Huruf Hijaiyah Berwarna Terhadap Kemampuan Membaca Huruf Al-Qur'an. JOEAI (Journal of Education and Instruction), 3(2). $\quad$ https://doi.org/https://doi.org/10.31539/joeai.v3i2.1388 PENGARUH.

Puspitasari, E., Setyosari, P., \& Amirudin, A. (2016). Peningkatan Motivasi Dan Hasil Belajar Melalui Think Pair Share (Tps) Di Sekolah Dasar. Jurnal Pendidikan - Teori, Penelitian, Dan Pengembangan, 1(7), 1432-1436. https://doi.org/10.17977/jp.v1i7.6589.

Rahayuningsih, S. S., Soesilo, T. D., \& Kurniawan, M. (2019). Peningkatan Kemampuan Mengenal Huruf Pada Anak Usia 5-6 Tahun Melalui Metode Bermain Dengan Media Kotak Pintar. Scholaria: Jurnal Pendidikan Dan Kebudayaan, 9(1), 11-18. https://doi.org/https://doi.org/10.24246/j.js.2019.v9.i1.p11-18.

Salawati, J. B., \& Suoth, L. (2020). Pengaruh Media Kartu Huruf Terhadap Kemampuan Membaca Permulaan. International Journal of Elementary Education, 4(1), 100. https://doi.org/10.23887/ijee.v4i1.24383

Surayya, L., Subagia, I. W., \& Tika, I. N. (2014). Pengaruh Model Pembelajaran Think Pair Share Terhadap Hasil Belajar IPA Ditinjau dari Keterampilan Berpikir Kritis Siswa. Jurnal Pendidikan Dan Pembelajaran IPA Indonesia, 4(1). https://ejournalpasca.undiksha.ac.id/index.php/jurnal_ipa/article/view/1105/0

Swastrini, K. C., Antara, P. A., \& Tirtayani, L. A. (2016). Penerapan Bermain Ular Tangga Untuk Meningkatkan Kemampuan Kerjasama Kelompok B1 di TK Widya Sesana Sangsit. Pendidikan Anak Usia Dini, https://doi.org/http://dx.doi.org/10.23887/paud.v4i2.7764

Tembang, Y., Sulton, \& Suharjo. (2017). Peningkatan Motivasi Dan Hasil Belajar Melalui 
Model Pembelajaran Think Pair Share Berbantuan Media Gambar Di Sekolah Dasar. Jurnal Pendidikan, 2(6), 812-817. http://journal.um.ac.id/index.php/jptpp/\%0AEISSN: 2502-471X

Uloli, R. (2021). Peningkatan Kemampuan Berbicara Anak Usia 3-4 tahun Menggunakan Pendekatan Think, Pair, and Share. Jurnal Obsesi : Jurnal Pendidikan Anak Usia Dini, 5(2), 1688-1695. https://doi.org/10.31004/obsesi.v5i2.997

Utaminingsih, R., Rahayu, A., \& Andini, D. W. (2018). Pengembangan RPP IPA sekolah dasar berbasis problem-based learning untuk siswa learning disabilities. Jurnal Inovasi Pendidikan IPA, 4(2), 191-202. https://doi.org/https://doi.org/10.21831/jipi.v4i2.21401

Winantara, I. W. D., \& Jayanta, I. N. L. (2017). Penerapan Model Pembelajaran Tps Untuk Meningkatkan Hasil Belajar IPA Siswa Kelas V SD No 1 Mengwitani. Jurnal Ilmiah Sekolah Dasar, 1(1). https://doi.org/http://dx.doi.org/10.23887/jisd.v1i1.10127

Yulsyofriend, Y., Anggraini, V., \& Yeni, I. (2019). Dampak Gudget Terhadap Perkembangan Bahasa Anak Usia Dini. Yaa Bunayya: Jurnal Pendidikan Anak Usia Dini, 3(1), 25. https://doi.org/https://doi.org/10.24853/yby.3.1.67-80 